\title{
Natural selection on cork oak: allele frequency reveals divergent selection in cork oak populations along a temperature cline
}

\author{
J. A. Ramírez-Valiente $\cdot$ Z. Lorenzo $\cdot$ A. Soto $\cdot$ F. Valladares $\cdot$ \\ L. Gil · I. Aranda
}

\begin{abstract}
A recent study of population divergence at neutral markers and adaptive traits in cork oak has observed an association between genetic distances at locus $Q_{p} \mathrm{ZAG} 46$ and genetic distances for leaf size and growth. In that study it was proposed that certain loci could be linked to genes encoding for adaptive traits in cork oak and, thus, could be used in adaptation studies. In order to investigate this hypothesis, here we (1) looked for associations between molecular markers and a set of adaptive traits in cork oak, and (2) explored the effects of the climate on among-population patterns in adaptive traits and molecular markers. For this purpose, we chose 9-year-old plants originating from thirteen populations spanning a broad range of climatic conditions. Plants established in a common garden site were genotyped at six nuclear microsatellites and phenotypically characterized for six functional traits potentially related to plant performance. Our results supported the proposed linkage between locus $Q p Z A G 46$ and genes encoding for leaf size and growth.
\end{abstract}

\author{
J. A. Ramirez-Valiente - I. Aranda \\ Instituto Nacional de Investigación y Tecnología Agraria y Alimentaria, Centro de Investigación \\ Forestal, Carretera Coruña Km 7.5, 28040 Madrid, Spain \\ e-mail: aranda@inia.es
}

\section{Z. Lorenzo - A. Soto - L. Gil . I. Aranda}

G.I. Genética y Fisiología Forestal. ETSI Montes Universidad Politécnica de Madrid, Ciudad Universitaria s/n, 28040 Madrid. Spain

J. A. Ramirez-Valiente - Z. Lorenzo - A. Soto - L. Gil - I. Aranda

Unidad Mixta de Genética y Ecofisiología Forestal INIA-UPM, Madrid, Spain

F. Valladares

Instituto de Recursos Naturales. Centro de Ciencias Medioambientales. CSIC, Serrano 115, 28006 Madrid, Spain

F. Valladares

Departamento de Biología y Geología. Escuela Superior de Ciencias Experimentales y Tecnológicas. Universidad Rey Juan Carlos, c/Tulipán s/n, 28933. Móstoles, Spain 
Temperature caused adaptive population divergence in leaf size and growth, which was expressed as differences in the frequencies of the alleles at locus $Q p Z A G 46$.

Keywords Quercus suber Natural selection - Overdominance Dominance . Additive effects - Adaptation

\section{Introduction}

Plants can respond to environmental heterogeneity by either exhibiting large phenotypic plasticity, i.e., great ability to express altemative phenotypes in response to environmental variation (Bradshaw 1965; Valladares et al. 2000, 2007), showing adaptations to their local environment (Kawecki and Ebert 2004; Savolainen et al. 2007), or both. Among-population differentiation in functional traits along an environmental gradient is one of the most widespread examples of local adaptation in wild populations. This process, known as adaptive divergence, generates genetic clines, which may be evident in allele diversity and the frequency of markers associated with genes encoding for adaptive traits (Rank and Dahlhoff 2002; Huestis and Marshall 2006; Mullen and Hoekstra 2008). These patterns of correlation between molecular diversity and the environment have been reported in several plant species including grasses Avena barbata (Hamrick and Allard 1972; Hamrick and Holden 1979), Hordeum spontaneum (Owuor et al. 1997, 2003) and Triticum dicoccoides (Li et al. 1999, 2000) and trees Betula pendula (Kelly et al. 2003), Pinus edulis (Cobb et al. 1994; Mitton et al. 1998; Mitton and Duran 2004), Picea engelmannii (Stutz and Mitton 1988; Mitton et al. 1989) and Fagus silvatica (Jump et al. 2006). However, although there are many examples of clines in allele frequencies in natural populations and sometimes the selective agent responsible for causing population genetic structure is even known, a precise understanding of the association between genetic markers and functional traits is often lacking in the context of natural selection (e.g., Mitton and Duran 2004; Jump et al. 2006). In fact, the genetic effects (e.g., overdominance, dominance, additive effects, etc.) underlying such associations are often ignored in these studies. Developing mechanistic hypotheses for such associations enables the evolutionary consequences of natural selection on the populations to be investigated. For instance, if alleles at a given locus (related to an adaptive trait) exhibit overdominance, the fitness of an heterozygous individual will be greater than either homozygote, resulting in the long-term persistence of multiple alleles in a population even under strong selective pressures (Watt et al. 1985; Watt 1992; Mitton 1997; Schmidt and Rand 2001). In contrast, if homozygous individuals exhibit higher fitness than heterozygotes at a given locus (e.g., by additive effects), natural selection eventually will lead to fixation of the favoured allele in the population (unless some form of balancing selection is acting) (Falconer and Mackay 1996; White et al. 2007).

Cork oak is an evergreen, wind-pollinated, outcrossing species distributed in the westem part of the Mediterranean Basin. As it occurs across a vast range of climatic conditions (Díaz-Fernández et al. 1995) and certain loci have been suggested to be linked to genes encoding for adaptive traits (Ramírez-Valiente et al. 2009a), this species provides a good model to explore the relationship between environmental clines and local adaptation. Studies on neutral molecular markers have shown a weak effect of neutral evolutionary processes such as genetic drift, founder effects and bottlenecks not derived from strong selection on the population structure of cork oak and few constraints to gene flow among populations (Toumi and Lumaret 1998; Jiménez et al. 1999; Ramírez-Valiente et al. 2009 a). In contrast, significant differences among populations have been reported for a 
broad set of growth parameters and functional traits (Aranda et al. 2005; Gandour et al. 2007; Ramírez-Valiente et al. 2009a, b) and adaptation to local climate has been viewed as the main factor responsible for such among-population divergence. As a consequence of climate warming, temperatures are expected to increase at least $2-4^{\circ} \mathrm{C}$ during this century within the cork oak distribution range (IPCC 2007). Thus, the selective pressures exerted by climate over this area are expected to increase. If this change is as rapid as expected, forest climatic zone boundaries could move quicker than forest tree species are able to migrate (Davis and Zabinski 1992; Higgins and Harte 2006), so their survival will increasingly depend on adaptation 'in situ' (Davis and Shaw 2001). Hence, more studies are necessary to determine the capacity of forest tree populations to cope with the environmental change expected for 21 st century.

In the present study, we have investigated the putative linkage of the six nuclear microsatellites to genes coding for adaptive traits, as suggested in a previous study (Ramírez-Valiente et al. 2009a). We examined the potential genetic effects underlying these associations: overdominance (heterozygote superiority), dominance and additive effects. We also examined whether there was a spatial pattern in the allele frequency of the loci associated with adaptive traits in 13 cork oak populations characterized by climatic differences at their place of origin. We expected that the different climate endured by the different populations had caused local adaptation, leading to a detectable pattern of different allelic frequencies for loci associated with adaptive traits (Kawecki and Ebert 2004; Savolainen et al. 2007). Finally, we explored the potential effects of climate change on cork oak populations and its possible evolutionary consequences.

\section{Materials and methods}

Study site and common garden

The study was conducted in a common garden experiment established in Monfragüe National Park, located in western Spain $\left(39^{\circ} 51^{\prime} \mathrm{N}, 6^{\circ} 1^{\prime} \mathrm{W}, 375 \mathrm{~m}\right.$, Cáceres). The climate is typically Mediterranean characterized by cool winters and hot dry summers. The mean annual precipitation is $755.2 \mathrm{~mm}$ and the mean annual temperature is $17.2^{\circ} \mathrm{C}$ for the period 1964-2005 at Serradilla meteorological station, $9 \mathrm{~km}$ from the common garden site (AEMET, National Meteorological Agency). The common garden was arranged in a randomized complete-block design. Thirteen populations spanning a broad range of climate conditions in cork oak were assayed (Table 1). Thirty blocks with four plants per population were set up. Seeds were collected in 1996 from 20 to 30 mother trees within each population. Seeds were sown at the beginning of 1997 and grown in the nursery for a year under standard conditions receiving ample water and nutrient availability, and then planted in field during the spring of 1998.

Phenotypic analysis

The ecophysiological study was carried out throughout 2005, a year characterized by dry and warm conditions ( $468.7 \mathrm{~mm}$ mean annual precipitation, $38 \%$ lower than the average value for the period 1964-2005). Spring and summer were particularly dry and AprilSeptember precipitation was only $96.9 \mathrm{~mm}$, compared to the average value of $167.2 \mathrm{~mm}$. Spring and summer were also warm with an average temperature of $23.9^{\circ} \mathrm{C}$ for this period $\left(1.5^{\circ} \mathrm{C}\right.$ higher than the average for the reference period; AEMET). 
Table 1 Location and climatic characterisation of the 13 cork oak populations and the common garden site during the study year (2005) and over a 7-year period following its establishment (1998-2005)

\begin{tabular}{|c|c|c|c|c|c|c|c|c|c|}
\hline Code & Population & Nearest locality & Latitude & Longitude & $\begin{array}{l}\text { Altitude } \\
\text { (m) }\end{array}$ & $\mathbf{P a}$ & Ps & $T$ & MMH \\
\hline POT & La Liebana region & Potes & $43^{\circ} 09^{\prime} \mathrm{N}$ & $4^{\circ} 37^{\prime} \mathrm{W}$ & 270 & 736 & 94.6 & 13.2 & 26.0 \\
\hline FIG & Catalonian Pyreenes & Figueras & $42^{\circ} 24^{\prime} \mathrm{N}$ & $2^{\circ} 48^{\prime} \mathrm{E}$ & 25 & 647 & 101.8 & 15.7 & 30.8 \\
\hline $\mathrm{COL}$ & Coastal catalonia & $\begin{array}{l}\text { Santa Coloma } \\
\text { de Famés }\end{array}$ & $41^{\circ} 54^{t} \mathrm{~N}$ & $2^{\circ} 30^{t} \mathrm{E}$ & 175 & 805 & 159.8 & 15.6 & 30.5 \\
\hline CR & Salamanca & Ciudad Rodrigo & $40^{\circ} 35^{\prime} \mathrm{N}$ & $6^{\circ} 26^{\prime} \mathrm{W}$ & 653 & 525 & 64.1 & 13.2 & 31.3 \\
\hline PAR & $\begin{array}{l}\text { Guadarrama } \\
\text { mountain range }\end{array}$ & El Pardo & $40^{\circ} 31^{\prime} \mathrm{N}$ & $3^{\circ} 45^{\prime} \mathrm{W}$ & 750 & 474 & 55.6 & 13.5 & 31.4 \\
\hline CB & Tietar valley & $\begin{array}{l}\text { Castillo de } \\
\text { Bayuela }\end{array}$ & $40^{\circ} 07^{\prime} \mathrm{N}$ & $4^{\circ} 31^{\prime} \mathrm{W}$ & 677 & 644 & 55.1 & 16.6 & 36.8 \\
\hline $\mathrm{CA}$ & North Caceres & El Cañaveral & $39^{\circ} 22^{\prime} \mathrm{N}$ & $6^{\circ} 22^{\prime} \mathrm{W}$ & 362 & 672 & 42.7 & 16.8 & 35.0 \\
\hline LV & $\begin{array}{l}\text { Las Villuercas } \\
\text { region }\end{array}$ & Cañamero & $39^{\circ} 22^{\prime} \mathrm{N}$ & $5^{\circ} 21^{\prime} \mathrm{W}$ & 600 & 1008 & 54.9 & 15.4 & 34.8 \\
\hline $\mathrm{ABU}$ & San Pedro hills & Alburquerque & $39^{\circ} 13^{\prime} \mathrm{N}$ & $7^{\circ} 13^{\prime} \mathrm{W}$ & 500 & 643 & 37.6 & 15.4 & 31.3 \\
\hline FUE & $\begin{array}{l}\text { Eastern Morena } \\
\text { mountain range }\end{array}$ & Fuencaliente & $38^{\circ} 24^{\prime} \mathrm{N}$ & $4^{\circ} 16^{\prime} \mathrm{W}$ & 670 & 432 & 38.9 & 14.8 & 33.3 \\
\hline $\mathrm{JC}$ & $\begin{array}{l}\text { Western Morena } \\
\text { mountain range }\end{array}$ & $\begin{array}{l}\text { Jerez de los } \\
\text { Caballeros }\end{array}$ & $38^{\circ} 13^{\prime} \mathrm{N}$ & $6^{\circ} 42^{\prime} \mathrm{W}$ & 492 & 627 & 39.1 & 16.1 & 33.5 \\
\hline $\mathrm{HZ}$ & $\begin{array}{l}\text { Las Alpujarras } \\
\text { region }\end{array}$ & Haza de Lino & $36^{\circ} 47^{\prime} \mathrm{N}$ & $3^{\circ} 18^{\prime} \mathrm{W}$ & 1300 & 607 & 24.5 & 13.0 & 29.3 \\
\hline ALM & $\begin{array}{c}\text { Los Alcomocales } \\
\text { National Park }\end{array}$ & $\begin{array}{l}\text { Castellar de la } \\
\text { Frontera }\end{array}$ & $36^{\circ} 16^{t} \mathrm{~N}$ & $5^{\circ} 22^{\prime} \mathrm{W}$ & 118 & 813 & 20.0 & 17.4 & 29.0 \\
\hline
\end{tabular}

$P a$ annual precipitation $(\mathrm{mm}), P_{s}$ summer precipitation $(\mathrm{mm}) . T$ mean annual temperature $\left({ }^{\circ} \mathrm{C}\right), M M H$ mean maximum temperature of the hottest month $\left({ }^{\circ} \mathrm{C}\right)$

For phenotypic characterization, a total of 15 blocks were selected and one plant per population was sampled within each block (13 populations $\times 15$ plants per population $=195$ plants in total). Growth parameters were measured in autumn to ensure that the vegetative season, which extends across spring and summer, had finished. Total height was determined in the selected saplings. Growth during 2005 was estimated through averaging the length of six shoots (with six different orientations) of the upper crown, all around the tree crown. We measured several phenotypic traits potentially related to drought tolerance and which have been found to be important for fitness in dry conditions (Dudley 1996; Donovan et al. 2007): leaf size, specific leaf area (SLA), nitrogen leaf content $\left(\mathrm{N}_{\text {mass }}\right)$ and carbon isotope discrimination $\left(\Delta^{13} \mathrm{C}\right)$. SLA is a measure of the projected leaf area per unit of dry weight and is related to the photosynthetic capacity and stomatal conductance (Reich et al. 1997). $\Delta^{13} \mathrm{C}$ is a surrogate of water use efficiency during the time for which the plant has fixed carbon (Farquhar et al. 1982; Farquhar and Richards 1984). Finally, leaf nitrogen, measured as the nitrogen mass per unit of leaf mass $\left(\mathrm{N}_{\text {mass }}\right)$ in mature leaves, is widely accepted to be associated to the investment in leaf photosynthetic components (especially Rubisco), and thus, influencing on the photosynthetic capacity. The measurements were carried out in spring leaves from three orientations (N, SE, SW). First, leaf size was estimated using the software WINFOLIA v. 2002 (Régent, Quebec, Canada). Then, leaves were dried in an oven at $65^{\circ} \mathrm{C}$ to a constant weight after scanning, to estimate SLA in one leaf per orientation. The rest of the dry material was used to analyze the isotopic composition of $\mathrm{C}^{13}$ and the nitrogen leaf content after grinding to fine powder using a ball mill. 
The 195 individuals phenotypically characterized were genotyped with six nuclear microsatellites transferred to cork oak from other $Q u e r c u s$ species: $Q p Z A G 9, Q p Z A G 15$, QpZAG46, developed in Q. petraea (Matts.) Liebl. (Steinkellner et al. 1997); QrZAG7, QrZAG11 and QrZAG20 developed in $Q$. robur L. (Kampfer et al. 1998). DNA was extracted from leaves following the method described by Doyle and Doyle (1990). Amplification and scoring were performed following Soto et al. $(2003,2007)$.

Statistical analyses

Deviation from Hardy-Weinberg equilibrium and linkage disequilibrium (LD) were tested using GENEFOP v4.0 (Raymond and Rousset 1995, Rousset 2008). We explored associations between phenotypic traits and molecular markers. For this purpose, (1) we evaluated the influence of single-locus heterozygosity on growth and ecophygiological traits by constructing general linear models (GLMs; one per trait) where phenotypic traits were the dependent variables and heterozygosity/homozygosity at each locus was fitted as fixed effect with two levels (e.g., Savolainen and Hedrick 1995). Thus, in this first analysis we exclusively distinguished between heterozygous and homozygous individuals without considering the genotype of specific alleles. (2) We examined the effect of the single-locus genotype on phenotypic traits. For that, we first constructed GLMs, where genotype of each locus was included as categorical variable and where the dependent variables were the different quantitative traits. Then, for those loci where genotype was associated with phenotypic traits, we implemented GLMs where the presence/absence of each allele was included as categorical variable with two levels and phenotypic traits as dependent variables. Owing to the effect of plant size on leaf morphology, structure, composition, growth and WUE (Casper et al. 2005) and in order to avoid possible spurious associations between molecular markers and phenotypic traits, initial height, measured as the plant height before the experiment, was included into the models as a covariate except when final height growth was analyzed. On the other hand, although few constraints to gene flow among populations and low level of population structure have been reported for cork oak (Toumi and Lumaret 1998; Jiménez et al. 1999; Ramírez-Valiente et al. 2009a), we followed the conservative criterion of fitting population as a categorical effect into the models to eliminate the possibility that false-positive associations between molecular markers and adaptive traits arise from population stratification originated by neutral evolutionary processes (Marchini et al. 2004; Hirschhorn and Daly 2005).

We also calculated the population frequencies for the alleles of those loci that were related to phenotypic traits. Then, we constructed generalized linear models (GLZs) with binomial error structure and log link function to test for differences in allele frequencies among populations. Likewise, we examined associations between allele frequencies and population average trait values. Finally, to evaluate the effects of climate as a selective agent, we explored the associations between allele frequencies and local climatic conditions (e.g., Mitton and Duran 2004).

Initially, each GLM was performed with all explanatory terms fitted. Final models were selected following a backward procedure, by progressively eliminating non-significant variables $(P>0.05)$. The significance of the remaining variables was tested again until no additional variable reached significance. STATISTICA 7.0 was employed to perform the statistical analyses. 
False discovery rate (FDR) corrections were applied for all analyses with repeated tests. The FDR was controlled at each p-level using a standard step-up procedure (see Benjamini and Hochberg 1995; García 2004).

\section{Results}

The mean number of alleles per locus was 6.2, and ranged from four to nine. These results are consistent with those obtained for the whole species range in the work of Burgarella et al. (2009). Despite the low level of polymorphism found in cork oak, moderately high heterozygosities were observed for most loci, except for QpZAG9 (Table 2). After FDR corrections, none of the populations deviated significantly from Hardy-Weinberg equilibrium at any locus (Table S1). Some loci showed linkage disequilibrium (LD) in certain populations (data not shown). Nevertheless, LD between loci had no effect on the associations between molecular markers and phenotypic traits, since only the locus QpZAG46 was involved in these associations (see results below) and it showed no linkage disequilibrium with other loci (data not shown).

Linkage disequilibrium and genotypic effects

There was no association between single-locus heterozygosity and phenotypic traits in any of the six markers (data not shown). On the contrary, when we studied the relationship between the genotype at each locus and phenotypic traits, there were clear differences in leaf size and growth correlated to the genotype at locus $Q p Z A G 46$ (Table 3, Fig. 1), but no other relationship for the rest of the variables and loci (data not shown). Genotype at locus QpZAG46 explained 13.1 and $3.6 \%$ of the phenotypic variance in height growth and leaf size, respectively. Homozygous individuals for allele $Q p Z A G 46-188$ (where 188 means

Table 2 Polymorphism characteristics of microsatellite loci used to type the 195 cork oak saplings

Table shows number of alleles (A), expected heterozygosity $\left(\mathrm{H}_{\mathrm{E}}\right)$ and observed heterozygosity $\left(\mathrm{H}_{\mathrm{O}}\right)$ for each locus

Table 3 General linear models for beight growth and leaf size in 9-year-old cork oaks in relation to population, genotype and injtial height (this only for leaf size)

Only genotypes with more than twenty individuals were analyzed. Only variables included in the models are indicated

\begin{tabular}{llll}
\hline Locus & $\mathrm{A}$ & $\mathrm{H}_{\mathrm{E}}$ & $\mathrm{H}_{\mathrm{O}}$ \\
\hline QpZAG9 & 5 & 0.17 & 0.17 \\
QpZAG15 & 7 & 0.52 & 0.50 \\
QpZAG46 & 4 & 0.61 & 0.57 \\
QrZAG7 & 9 & 0.71 & 0.66 \\
QrZAG11 & 8 & 0.67 & 0.64 \\
QrZAG20 & 4 & 0.66 & 0.61 \\
\hline
\end{tabular}

\begin{tabular}{lll}
\hline & Test & $P$ \\
\hline Height growth & & \\
Population & - & - \\
QpZAG46 genotype & $F_{\mathrm{t}, 166}=4.52$ & 0.003 \\
Leaf size & & \\
Population & - & - \\
QpZAG46 genotype & $F_{4,166}=4.11$ & 0.003 \\
Initial height & $F_{\mathrm{t} .166}=12.37$ & $<0.001$ \\
\hline
\end{tabular}



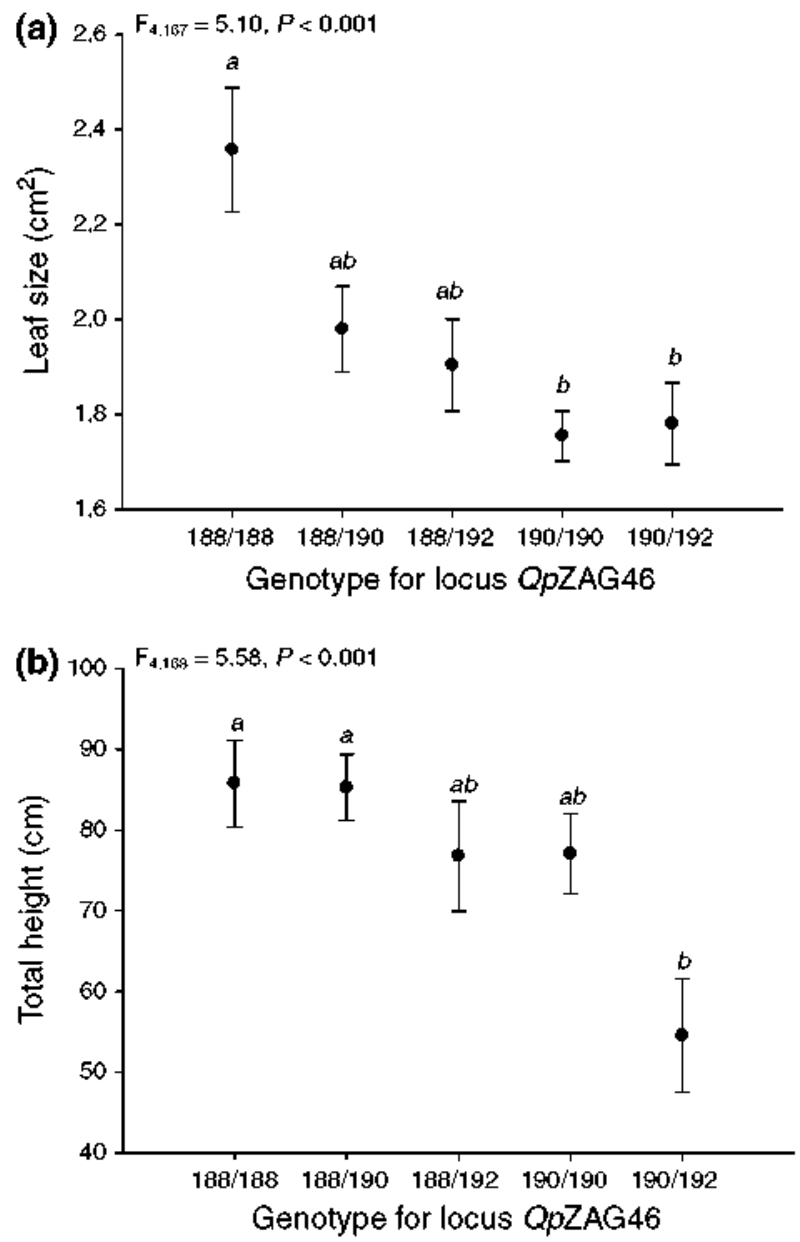

Fig. 1 Mean \pm SE leaf size (a) and total height (b) for the different genotypes for locus $Q p Z A G 46$. Homogeneous genotypes at $95 \%$ contidence intervals are indicated by the same letter

the number of the base pairs) had the largest leaves (Fig. 1a) and the highest growth (Fig. 1b). Likewise, we explored for single-allele associations between locus QpZAG46 and height growth and leaf size. After controlling for population structure and initial height (this only for leaf size), we found that the presence of allele QpZAG46-188 was positively associated with 8-year growth in height whereas OpZAG46-192 allele had a negative association with it (Table 4). Allele QpZAG46-188 was also marginally associated to a larger leaf size, whereas individuals carrying $Q p Z A G 46-190$ had significantly smaller leaves (Table 4).

Gene frequency and temperature clines

There were no effect of population on height growth and leaf size after controlling for genotype at $Q p Z A G 46$ or initial height (this only for leaf size; Table 3). We explored population divergence in the frequency of $Q p Z A G 46$ allele. Frequency of $Q p Z A G 46-188$ 
Table 4 Tests for the effects of the presence/absence of each single allele of $Q p Z A G 46-l o c u s$ in relation to leaf size and height growth

\begin{tabular}{|c|c|c|c|c|c|c|}
\hline & \multicolumn{3}{|l|}{ Leaf size } & \multicolumn{3}{|l|}{ Height growth } \\
\hline & Estimate $\pm \mathrm{SE}$ & $F$ & $P$ & Estimate \pm SE & $F$ & $P$ \\
\hline QpZAG46-188 & & 3.31 & 0.071 & $-0.056 \pm 0.013$ & 18.13 & $<0,001^{\text {**** }}$ \\
\hline QpZAG46-190 & $0.072 \pm 0.021$ & 11.27 & $<0.001^{* *}$ & & 1.02 & 0.313 \\
\hline QpZAG46-192 & & 0.01 & 0.926 & $0.051 \pm 0.016$ & 10.72 & $0.001^{* * *}$ \\
\hline
\end{tabular}

Only alleles present in more than 20 individuals were analyzed. Parameter estimates and SE were calculated considering a zero reference value for the presence of each allele. Parameter estimates were included only for significant variables

Asterisks indicate the level of significance after applying FDR correction for multiple tests
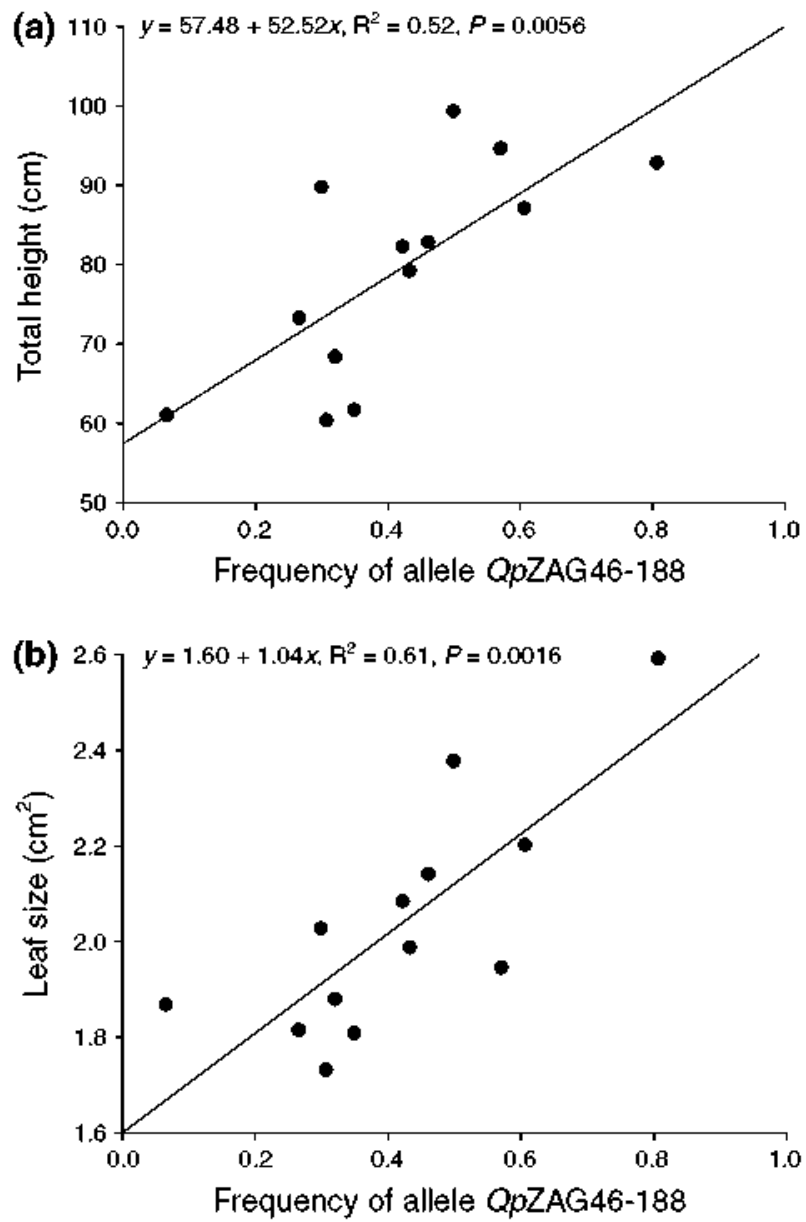

Fig. 2 Relationship between the frequency of the allele $Q p Z A G 46-188$ and average total height (a) and leaf size (b) for 13 populations of Quercus suber 

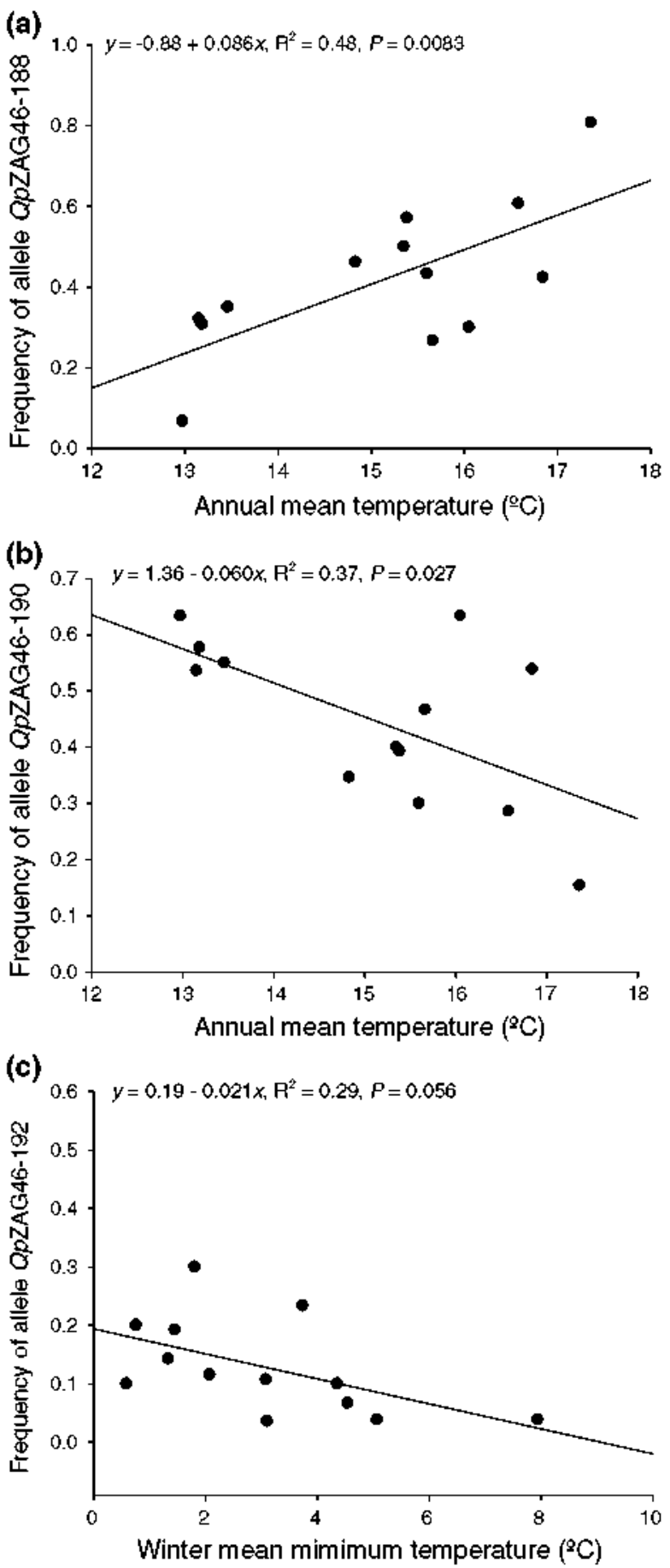

Fig. 3 Relationships between climatic parameters and the frequency of the alleles QpZAG46-188 (a), QpZAG46-190 (b) and QpZAG46-192 (c) for 13 populations of Quercus suber 
and $Q p Z A G 46-190$ differed among populations $(Z=27.081, P=0.008$ and $Z=22.073$, $P=0.037$, respectively), but not that of $Q p Z A G 46-192(Z=18.86, P=0.092)$. We found a positive relationship between the proportion of alleles 188 and 190 , and the population mean of height growth and leaf size (Fig. 2a, b) but not between allele 192 and these quantitative traits $(r=-0.55, P=0.051$ for height growth and $r=-0.39$, $P=0.189$ for leaf size). Finally, we found a positive effect of the annual mean temperature (AMT) on the population frequency of allele $Q p Z A G 46-188$ and a negative effect of AMT on $Q p Z A G 46-190$ (Fig. 3a, b). Frequency of allele $Q p Z A G 46-192$ showed a marginal negative association with AMT ( $r=-0.48, P=0.085)$ and it had a trend to be significant and negatively associated to winter minimum temperature (Fig. 3c).

\section{Discussion}

Linkage disequilibrium and genotypic effects

In this study, we show an association between locus $Q p Z A G 46$ and leaf size and growth, suggesting a possible linkage between this locus and genes coding for these phenotypic traits. Additionally, the possibility that $Q p Z A G 46$ is included in a transcribed region and have a direct effect on the studied trait, although unlikely, cannot be ruled out. This association supports our previous work based on among-population genetic differentiation $\left(Q_{\mathrm{ST}}\right)$ for leaf size and growth strongly correlated with among-population genetic distance $\left(\mathrm{F}_{\mathrm{ST}}\right.$ ) for locus $Q p Z A G 46$, but not for other microsatellites (Ramírez-Valiente et al. 2009a). Our results agree with other studies on oaks, which report that $Q p Z A G 46$ belongs to the same linkage group as QrZAG87 and QpZAG119 (Scotti-Saintagne et al. 2004; Brendel et al. 2008), close to a QTL coding for leaf size (Brendel et al. 2008).

Single-locus heterozygosity per se had no effect on phenotypic traits. In other words, heterozygotes for each single-locus did not exhibit either different leaf size or growth compared to homozygotes. This indicates that the overdominance hypothesis (i.e., heterozygosity superiority) is not the underlying mechanism that explains the observed association between QpZAG46 and adaptive traits. In contrast, the association between QpZAG46 and phenotypic traits was dependent on the type of alleles (i.e., genotype). Genotype at this locus explained the 3.6 and $13.1 \%$ of the phenotypic variance in leaf size and height growth, respectively, which represents considerably high values for association studies in forest tree species (e.g. Thumma et al. 2005; Gonzalez-Martínez et al. 2007, 2008 ). Furthermore, the fact that, (1) allele $Q p Z A G 46-188$ was positively associated with leaf size, (2) the homozygotes $188 / 188$ showed larger leaves than heterozygotes for this allele, although not significantly, and (3) the homozygous individuals for allele 190, an allele negatively related to leaf size, had smaller leaves than heterozygotes for this allele, suggest that the allele/s of the gene/s involved in this trait and linked to $Q p Z A G 46-188$ has/ have a (partially) dominant effect.

Unexpectedly, although $Q p Z A G 46$ genotypes varied in leaf size (a trait broadly documented to be associated to plant growth, e.g., Dudley 1996; Donovan et al. 2007), they did not differ in annual shoot growth during the study year. However, they did vary in accumulated height growth. The reason why divergence in leaf size could lead to differences in height over 8 years, but not to differences in growth during 2005 could be related to the particularly low water-availability for this year, which could have reduced the advantage of certain generally fast-growing genotypes (Aranda et al. 2007). Likewise, the potential higher capability of large-leaved genotypes to take advantage of wetter years may 
explain the differences in accumulated height growth (Ramírez-Valiente et al., unpublished data). Nevertheless, although there were differences among $Q p Z A G 46$-genotypes in both leaf size and height growth, the pattern of among-genotype divergence in the former did not exactly correspond to the pattern found in the latter (Fig. 1). One potential explanation for the observed pattem could be that both traits have different threshold limits regarding the genotype. Alternatively, since the locus $Q p Z A G 46$ explained more phenotypic variance for height $(13.1 \%)$ than for leaf size $(3.6 \%)$, an explanation which can not be ruled out, could be that locus QpZAG46 is also associated to genes encoding for other traits related to growth.

Adaptive differentiation and evolutionary response to climate change of cork oak populations

Cork oak populations were exceptionally differentiated at the locus $Q p Z A G 46$. The population frequency of allele $Q p Z A G 46-188$ was positively correlated with AMT at the place of origin, whereas the population probability of the presence of alleles QpZAG46190 and $Q p Z A G 46-192$ increased as annual and winter temperatures dropped. These results, together with the fact that $Q p Z A G 46$-alleles had different effects on adaptive traits, suggest that temperature is a relevant selective agent for cork oak and its selective pressures lead to the development of local adaptations (e.g., Aranda et al. 2005; RamírezValiente et al. $2009 \mathrm{a}$ ). In view of these results and given that constraints to gene flow among populations are weak (Toumi and Lumaret 1998; Jiménez et al. 1999), adaptive pressures can be expected to be the main factor responsible of genetic differentiation at the locus, consistently with previous results (Ramírez-Valiente et al. 2009a).

However, since $Q p Z A G 46$ showed an association with leaf size and growth, and given that different alleles and genotypes at this locus seem to be favoured under different temperatures, significantly positive $\mathrm{F}_{\mathrm{IS}}$ values at this locus could be expected (White et al. 2007). Nevertheless, our results show no deviation from HWE. A feasible explanation could be that the selective pressure on the gene/s related to the studied traits and linked to $Q_{p Z A G 46}$ is not extremely strong, as could be expected for a gene without a major effect on fitness at the studied stage. A (partially) dominant effect of such gene/s could also account for these results. In addition, interactions with other loci, favouring certain heterozygotes, cannot be discarded.

The role of temperature as a selective agent influencing the allele frequencies in cork oak populations also had consequences for polymorphism at locus $Q p Z A G 46$. For instance, allele $Q p Z A G 46-188$ was almost fixed (frequency $>0.8$ ) in some warm populations. This effect of temperature on cork oak polymorphism could be of special relevance in the context of climate change. Thus, an increase in the severity of droughts and frequency of high temperatures periods expected in the Mediterranean basin during 21st century (IPCC 2007) is likely to cause stronger selective pressures for the species inhabiting this area. In the particular case of cork oak, as individuals carrying allele $Q_{p}$ ZAG46-188 had larger leaf sizes, especially homozygotes, and as they were favoured under higher temperatures, an increase in temperatures along the distribution range of cork oak is expected to cause an increase in the frequency of this allele (e.g., Kelly et al. 2003; Jump et al. 2006). However, the frequency of this allele also showed a marginal positive association with annual precipitation $(r=0.52, P=0.065)$, suggesting that having larger leaves may be benefited under higher temperatures exclusively if they are coupled with higher rainfalls. 
In conclusion, our study revealed evidence of linkage between locus QpZAG46 and genes encoding for leaf size and growth in cork oak. Temperature caused adaptive population divergence in leaf size and growth, which was expressed as differences in the frequencies of the alleles at locus $Q_{p} \mathrm{ZAG} 46$.

Acknowledgments This study was funded by the Spanish Ministry of Environment and DGB (Convenio UPM-DGB), the Spanish Ministry of Science and Innovation (PLASTOFOR, AGL-00536/FOR and BOSALIM, CGL2007-66066-C04-02/CGL2007-66066-C04-03 projects and BES-2005-7573 fellowship). We thank Pedro Díaz-Femández. Laura Castro, Regina Chambel. José María Climent, Pilar Jiménez and the rest of the people who collaborated in the setting up of the cork oak field common gardens under the EU concerted action on cork oak. FAIR I CT 95 0202. We thank to AEMET (Agencia estatal de Meteorología) for providing the climatic data. We thank Matthew Robson who made a thorough review of the English version and contributed with valuable suggestions. We thank Santiago de. Blas, José Antonio Mancha and other field assistants for their help during the experiment. We are grateful to Salustiano Iglesias and DGB for the maintenance of the common gardens. Finally, we would like to thank to Santiago González-Martínez for his useful suggestions and comments on the final version of the manuscript.

\section{References}

Aranda I, Castro L, Alía R. Pardos JA, Gil L (2005) Low temperature during winter elicits differential responses among populations of the Mediterranean evergreen cork oak (Qtercts stber). Tree Physiol 25:1085-1090

Aranda I, Pardos M. Puértolas J, Jiménez MD. Pardos JA (2007) Water use efficiency in cork oak (Quercus suber $\mathbf{L}$.) is modified by the interaction of water and light availabilities. Tree Physiol 27:671-677

Benjamini Y, Hochberg Y (1995) Controlling the false discovery rate: a practical and powerful approach to multiple testing. J Roy Stat Soc 57:289-300

Bradshaw AD (1965) Evolutionary signiticance of phenotypic plasticity in plants. Adv Genet 13:115-155

Brendel O. Le Thiec D, Scotti-Saintagne C. Kremer A, Guehl JM (2008) Quantitative trait loci controlling water use efficiency and related traits in Quercus robur L. Tree Genet Genom 4:263-278

Burgarella C, Lorenzo Z, Jabbour-Zahab R, Lumaret R, Guichoux E. Petit RJ, Soto A, Gil L (2009) Detection of hybrids in nature: application to oaks (Quercus stber and Q.ilex). Heredity 102:442-452

Casper BB. Forseth IN, Wait DA (2005) Variation in carbon isotope discrimination in relation to plant performance in a natural population of Cryptantha flava. Oecologia 145:541-548

Cobb N, Mitton JB, Whitham TG (1994) Genetic variation associated with chronic water and nutrient stress in pinyon pine. Am J Bot 81:936-940

Davis MB, Shaw RG (2001) Range shifts and adaptive responses to quatemary climate change. Science 292:673-679

Davis MB, Zabinski C (1992) Changes in geographical range resulting from greenhouse warming effects on biodiversity in forests. In: Peters RL. Lovejoy TL (eds) Global warming and biological diversity. Yale University Press, New Haven, pp 298-308

Díaz-Femández PM. Jiménez P. Catalán G. Martín S. Gil L (1995) Regiones de procedencia de Quercus suber $\mathrm{L}$. ICONA. Madrid $49 \mathrm{p}$

Donovan LA. Dudley SA. Rosenthal DM, Ludwig F (2007) Phenotypic selection on leaf water use efticiency and related ecophysiological traits for natural populations of desert sunflowers. Oecologia 152:13-25

Doyle J, Doyle J (1990) Isolation of plant DNA from fresh tissue. Focus 13:13-15

Dudley SA (1996) Differing selection on plant physiological traits in response to environmental water availability: a test of adaptive hypotheses. Evolution 50:92-102

Falconer DS, Mackay TFC (1996) Introduction to quantitative genetics. Longman, Essex

Farquhar GD, Richards RA (1984) Isotopic composition of plant carbon correlates with water-use efficiency of wheat genotypes. Aust J Plant Physiol 11:539-552

Farquhar GD. O'Leary MH. Berry JA (1982) On the relationship between carbon isotope discrimination and the intercellular carbon dioxide concentration in leaves. Aust J Plant Physiol 1:121-137

Gandour M. Khouja ML. Toumi L. Triki S (2007) Morphological evaluation of cork oak (Quercus suber): Mediterranean provenance variability in Tunisia. Ann Forest Sci 64:549-555

García LV (2004) Escaping the Bonfertoni iron claw in ecological studies. Oikos 105:657-663 
Gonzalez-Martinez SC, Wheeler NC, Ersoz E, Nelson CD, Neale DB (2007) Association genetics in Pinus taeda L. I. Wood property traits. Genetics 175:399-409

González-Martínez SC, Huber D, Ersoz E. Davis JM. Neale DB (2008) Association genetics in Pinus taeda L. II. Carbon isotope discrimination. Heredity 101:19-26

Hamrick JL, Allard RW (1972) Microgeographical variation in allozyme frequencies in Avena barbata. Proc Natl Acad Sci USA 69:2100-2104

Hamrick JL, Holden LR (1979) Infuence of microbabitat heterogeneity on gene frequency distribution and gametic phase disequilibrium in Avena barbata. Evolution 33:521-5:33

Higgins PAT, Harte J (2006) Biophysical and biogeochemical responses to climate change depend on dispersal and migration. Bioscience 56:407-417

Hirschhorn JN, Daly MJ (2005) Genome-wide association studies for common diseases and complex traits. Nat Rev Genet 6:95-108

Huestis DL, Marshall JL (2006) Is natural selection a plausible explanation for the distribution of Idh-1 alleles in the cricket Allonemobius socius? Ecol Entomol 41:91-98

IPCC (2007) Climate change 2007: the physical basis. contribution of working group $\mathrm{i}$ to the fourth assessment of the intergovemmental panel on climate change. IPCC Secretariat. Geneva. Switzerland

Jiménez P. Agundez D. Alia R. Gil L (1999) Genetic variation in central and marginal populations of Quercus suber L. Silvae Genet 48:278-284

Jump AS, Hunt JM. Martinez-Izquierdo JA, Peñuelas J (2006) Natural selection and climate change: Temperature-linked spatial and temporal trends in gene frequency in Fagis sylvatica. Mol Ecol $15: 3469-3480$

Kampfer S, Lexer C. Glössl J, Steinkellner H (1998) Characterization of (GA) microsatellite loci from Quercus robur. Hereditas 129:183-186

Kawecki TJ, Ebert $\mathbf{T}$ (2004) Conceptual issues in local adaptation. Ecol Lett 7:1225-1241

Kelly CK, Chase MW, de Brujin A. Fay MF. Woodward FI (2003) Temperature-based population segregation in birch. Ecol Lett 6:87-89

Li YC, Fahima T. Beiles A, Korol AB. Nevo E (1999) Microclimatic stress and adaptive DNA differentiation in wild emmer wheat, Triticum dicoccoides. Theor Appl Genet 98:873-883

Li YC, Fahima T, Krugman T, Krugman T, Beiles A, Röder MS, Korol AB, Nevo E (2000) Parallel microgeographic patterns of genetic diversity and divergence revealed by allozyme, RAPD. and microsatellites in Triticum dicoccoides at Ammiad. Israel. Conserv Genet 1:191-207

Marchini J. Cardon LR. Phillips MS. Donnelly P (2004) The effects of human population structure on large genetic association studies. Nat Genet 36:512-517

Mitton JB (1997) Selection in natural populations. Oxford University Press, New York

Mitton JB, Duran KL (2004) Genetic variation in pinyon pine. Pinus edifis, associated with summer precipitation. Mol Ecol 13:1259-1264

Mitton JB, Stutz HP, Schuster WSF. Shea KL (1989) Genotypic differentiation at PGM in Engelmann spruce from wet and dry sites. Silvae Genet 38:217-221

Mitton JB, Grant MC, Yoshino AM (1998) Variation in allozymes and stomatal size in pinyon (Pinus edulis, Pinaceae). associated with soil moisture. Am J Bot 85:1262-1265

Mullen LM. Hoekstra HE (2008) Natural selection along an environmental gradient: a classic cline in mouse pigmentation. Evolution 62-7:1555-1570

Owuor ED, Fahima T, Beiles A, Korol A, Nevo E (1997) Population genetic response to microsite ecological stress in wild barley, Hordeum spontaneum. Mol Ecol 6:1177-1187

Owuor ED. Beharav A. Fahima T, Krzhner VM. Korol AB. Nevo E (2003) Microscale ecological stress causes RAPD molecular selection in wild barley, Neve Yaar microsite, Israel. Genetic Resour Crop Evol 50:213-223

Ramírez-Valiente JA, Valladares F, Gil L, Aranda I (2009a) Population differences in juvenile survival under increasing drought are mediated by seed size in cork oak (Quercus suber L.). Forest Ecol Manag 257:1676-1683

Ramírez-Valiente JA. Lorenzo Z. Soto A. Valladares F. Gil L. Aranda I (2009b) Elucidating the role of genetic drift and natural selection in cork oak differentiation regarding drought tolerance. Mol Ecol $18: 3803-3815$

Rank NE, Dahlhoff EP (2002) Allele frequency shifts in response to climate change and physiological consequences of allozyme variation in a montane insect. Evolution 56:2278-2289

Raymond M. Rousset F (1995) GENEPOP (version 1.2): population genetics software for exact tests and ecumenicism. J Hered $86: 248-249$

Reich PB, Waters MB. Ellsworth DS (1997) From tropics to tundra: global convergence in plant functioning. Proc Natl Acad Sci USA 94:13730-13734 
Rousset F (2008) Genepop 007: a complete reimplementation of the Genepop software for Windows and Linux. Mol Ecol Resour 8:103-106

Savolainen O, Hedrick P (1995) Heterozygosity and fitness: no association in Scots Pine. Genetics 140: $755-766$

Savolainen O. Pyhajarvi T, Knurr T (2007) Gene fow and local adaptation in trees. Annu Rev Ecol Evol Syst 38:595-619

Schmidt PS. Rand DM (2001) Adaptive maintenance of genetic polymorphism in an intertidal barnacle: habitat- and life-stage-specific survivorship of MPI genotypes. Evolution 55:1336-1344

Scotti-Saintagne C, Mariette S. Porth I, Goiecoechea PG. Barreneche T. Bodénès C, Burg K, Kremer A (2004) Genome scanning for interspecitic differentiation between two closely related oak species (Quercus robur $\mathbf{L}$. and Q. petraea (Matt.) Liebl.). Genetics 168:1615-1626

Soto A. Lorenzo Z, Gil L (2003) Nuclear microsatellite markers for the identification of Quercus ilex L. and Q. suber L. hybrids. Silvae Genet 52:63-66

Soto A, Lorenzo Z. Gil L (2007) Differences in tine-scale genetic structure and dispersal in Quercus ilex L. and Q. suber $\mathbf{L}$ : consequences for regeneration of mediterranean open woods. Heredity 99:601-607

Steinkellner H, Fluch S, Turetschek E. Lexer C, Streiff R. Kremer A. Burg K. Glossl J (1997) Identification and characterization of (GA/CT) n-microsatellite loci from Quercus petraea. Plant Mol Biol 33: 1093-1096

Stutz HP, Mitton JB (1988) Genetic variation in Engelmann spruce associated with soil moisture. Arct Alp Res 20:461-465

Thumma BR, Nolan MR, Evans R, Moran GF (2005) Polymorphisms in cinnamoyl CoA reductase (CCR) are associated with variation in microfibril angle in Eucalyptus spp. Genetics 171:1257-1265

Toumi L, Lumaret $\mathbf{R}$ (1998) Allozyme variation in cork oak (Quercus suber L.): the role of phylogeography and genetic introgression by other Mediterranean oak species and human activities. Theor Appl Genet $97: 647-656$

Valladares F, Wright SJ, Lasso E, Kitajima K, Pearcy RW (2000) Plastic phenotypic response to light of 16 congeneric shrubs from Panamanian rainforest. Ecology 81:1925-1936

Valladares F, Gianoli E, Gómez JM (2007) Ecological limits to plant phenotypic plasticity. New Phytol $146: 749-763$

Watt WB (1992) Eggs. enzymes. and evolution: natural genetic variants change insect fecundity. Proc Natl Acad Sci USA 89:10608-10612

Watt WB, Carter PA, Blower SM (1985) Adaptation at specitic loci. IV. Differential mating success among glycolytic allozyme genotypes of Colias butterflies. Genetics 109:157-175

White TL. Adams WT, Neale DB (2007) Forest genetics. CAB International, Wallingford, UK 